RESEARCH ARTICLES

\title{
The Exercise Vibration Wave Principle in Physical Rehabilitation of Children with Musculoskeletal System Disorders
}

\section{El principio de onda vibratoria durante el ejercicio en la rehabilitación física de niños con trastornos del sistema musculoesquelético}

\begin{abstract}
Nikolai Nikolaevich Efimenko
Doctor of Pedagogical Sciences, Professor, Department of Applied Psychology and Speech Therapy. Berdyansk State Pedagogical University, Berdyansk, Ukraine. https://orcid.org/0000-0001-7539-8007

Volodymyr Vyktorovych Biesieda

Candidate of Pedagogical Sciences, doctoral student, Department of Orthopedagogy, Rehabilitation, and Orthopsychology. M.P. Dragomanov Kyiv National State Pedagogical University, Kyiv, Ukraine. https://orcid.org/0000-0003-4262-6629
\end{abstract}

Mykhailo Vyctorovych Litvyakov

Physical education teacher. Municipal Institution "Rehabilitation Center for Persons with mental and physical Developmental Disabilities", Odesa, Ukraine.

https://orcid.org/0000-0002-4750-915X

Received 09-08-20 Revised 10-10-20

* Correspondence

Email: efimnn1958@gmail.com
Accepted 12-12-20 On line 03-17-21

Citation:

Nikolai Nikolaevich Efimenko, Volodymyr Vyktorovych Biesieda, Mykhailo Vyctorovych Litvyakov. (2021). The Exercise Vibration Wave Principle in Physical Rehabilitation of Children with Musculoskeletal System Disorders. Propósitos y Representaciones, 9 (SPE3), e1166. Doi http://dx.doi.org/10.20511/pyr2021.v9nSPE3.1166 


\begin{abstract}
The article describes the methodical and methodological possibilities of the vibration-wave principle of physical exercises in the context of its use in the physical rehabilitation of children with musculoskeletal disorders both in the conditions of the hall for movement therapy and in the aquatic environment using the example of hydrokinesis therapy. The analysis of the well-known healing properties of vibration on the human body, which can be used in the physical rehabilitation of children with musculoskeletal system disorders, is given. The known possibilities of acoustic wave effects on the musculo-fascial and skeletal systems of people are analyzed. The unique possibilities of applying the phenomena of vibration and waves not only on land but also in an aquatic environment, in conditions of hydrokinesis therapy in a pool are considered. The properties of a longitudinal elastic (acoustic) wave and its effect on the musculoskeletal system of children are characterized. The authors proposed a new concept in physical rehabilitation - "correctional acoustic internal field" on land and "correctional hydroacoustic external field" (in water). The methodological aspects of the varieties of using these fields in an autoactive (independent, conscious) version and in an imperative (forced, directing from the outside) version are considered.
\end{abstract}

Keywords: wave, vibration, principle, physical rehabilitation, children.

\title{
Resumen
}

El artículo describe las posibilidades metódicas y metodológicas del principio de vibración-onda de los ejercicios físicos en el contexto de su uso en la rehabilitación física de niños con trastornos musculoesqueléticos tanto en las condiciones de la sala de terapia del movimiento como en el medio acuático utilizando el ejemplo de la terapia de hidrocinesis. Se da el análisis de las conocidas propiedades curativas de la vibración en el cuerpo humano, que pueden utilizarse en la rehabilitación física de niños con trastornos del sistema musculoesquelético. Se dan las posibilidades conocidas de los efectos de las ondas acústicas en el músculo -Se analizan los sistemas fascial y esquelético de las personas. Se consideran las posibilidades únicas de aplicar los fenómenos de vibración y ondas no solo en tierra sino también en un medio acuático, en condiciones de hidrocinesis terapéutica en una piscina. Se consideran las propiedades de un elástico longitudinal ( acústica) y su efecto sobre el sistema musculoesquelético de los niños. Los autores propusieron un nuevo concepto en rehabilitación física: "campo interno acústico correccional" en tierra y "campo externo hidroacústico correccional" (en agua). Los aspectos metodológicos de las variedades de uso de estos campos en una versión autoactiva (independiente, consciente) y en Se considera una versión imperativa (forzada, dirigida desde el exterior).

Palabras clave: ola, vibración, principio, rehabilitación física, niños.

\section{Introduction}

The unique properties of the water environment have been used for a long time in the medical rehabilitation of adults with musculoskeletal system disorders in specialized centers, sanatoriums, and hospitals. First of all, this concerns the unique ability of water to reduce the gravitational load on the spinal column, on its damaged brain and articular structures. In water, the bodyweight of a person is decreased by about $9 / 10$, which allows the patient to successfully perform the necessary therapeutic exercises for hydrokinesis therapy. But the analysis of the available literary sources showed insufficient issues development of hydrocorrection of children of early, preschool, and primary school age with various musculoskeletal system disorders: infantile cerebral palsy, spinal paralysis and paresis, combined cerebrospinal injuries, and the like (Efimenko, Litvyakov, 2019). To a large extent, this concerns the vibration-wave phenomenon, which can be realized when performing the appropriate exercises not only on land but also in water. This has determined the relevance of this study. 


\section{Problem statement}

In our research, we started from the N. I. Kudryashov theory about the system of integral wave motion (SIWM) (Kudryashov, 2011) and its effect on the human body. We can talk about the general healing exercise vibration-wave principle, which can be used in the physical development of children (Efimenko 2013). We are interested in the mechanism of using the wave effect in the physical rehabilitation of children with musculoskeletal system disorders in the conditions of movement therapy on land and hydrokinesis therapy in the pool.

\section{Research questions}

First of all, we are interested in the mechanism of elastic wave formation. In the theory of wave processes (Solovyanova, Shabunin, 2004), a wave is any change (perturbation) of the medium state, propagating with a finite speed and carrying energy. All waves can be divided into two types: elastic and electromagnetic. In our study, we are interested in elastic waves. Elastic (also known as acoustic) waves are waves associated with vibrations of particles during mechanical deformation of an elastic medium (liquid, gaseous, solid). In this case, the transfer of elastic deformation energy takes place during the absence of matter transfer. An example of acoustic waves is sound waves, which are represented as areas of high and low air pressure, radiating from the sound source. In an acoustic wave, the particles of the medium vibrate around the rest point. A wave, in which the oscillatory velocity vector is parallel to the direction of propagation is called a longitudinal wave. If a stationary medium is represented as a regular structure, then in the case of a longitudinal wave, compression and rarefaction regions will alternate along the direction of wave propagation. This longitudinal acoustic wave can be used to solve various problems in the physical rehabilitation of children with musculoskeletal system disorders. This determines the relevance of this study.

\section{Purpose of the study}

The purpose of the article is to analyze the possibilities of the vibration-wave principle of exercises in land and water conditions on the example of physical rehabilitation of children with musculoskeletal disorders.

\section{Research methods}

To make this research, we used the following methods:

theoretical analysis of the available literature on the problems of vibration-wave influences on the human body - to form the concept of using the vibration-wave principle in the physical rehabilitation of children with musculoskeletal system disorders;

modeling of wave effects on the musculoskeletal system of children in land and water conditions - to develop a methodological basis for using the vibration-wave effect in the children physical rehabilitation;

pedagogical observations of specially organized wave movements of children on land and in the pool - to identify effective uses of wave movements in the physical development correction of children with musculoskeletal system disorders;

ascertaining pedagogical experiment - to identify the influence of the anti-gravity phenomenon of the aquatic environment and the wave effects of water in the pool on the musculoskeletal system of preschool children.

\section{Findings}

Such positive effects of vibration have been known in medical physical culture and massage (Efimenko, 2013; Kudryashov, 2011):

- $\quad$ during vibration, there is a general relaxation of muscle fibers and fascia;

- vibration (shaking) allows to reduce spasticity degree in certain muscle groups, especially in limbs; 
activity;
phenomenon"); vibration of the average rhythm allows to tune the life cycle to another rhythm of
$\quad$ vibrations of muscle fibers take place in the range of sound frequencies, that's why the effect of movements is enhanced when they are performed with sound accompaniment;

- body-muscular-articular vibrations are carried out mainly in the range of 7-15 Hz (relatively low-frequency vibrations). greater amplitude.

the wave impact is also a kind of vibration, but carried out smoothly, with a

The wave movement elements usage in the physical development of children allows achieving such corrective effects (Borshchenko, 2011; Efimenko 2013; Kudryashov, 2011):

- $\quad$ wave gymnastics for the deep muscles of the back and spine, which includes lowfrequency vibrations, fluctuations, shaking the whole body, produces a wave of micro-movements from the vertebra to the vertebra, which allows to relax these deep muscles, which are quite often in a state of chronic spasm (especially in case of disorders posture);

- $\quad$ the wave principle of left-right movements with a frequency of 6-10 movements per minute, incorporated in the "pendulum" principle, allows better to harmonize the activity of spasmodic muscles on the concave side of the spine and stretched muscles on the convex side;

- the body wave harmonizes all parts of the body for the common center of mass: the upper body from the lower, the left side from the right, the left arm - right leg diagonal with the right arm - left leg diagonal (myofascial meridians), etc.;

edema effect;

low-frequency body movements have anesthetic, anti-inflammatory and anti-

- wave movements at their rates coincide with the rate of activity of the main functional systems of the body, act as if in unison with them: respiratory rate, heart rate in the supine position, alpha-rhythm of the brain; here we should also mention the phenomenon of the "three-second rhythm", recorded in involuntary human movements (shaking the head in agreement, scratching, waving the hand at parting, squeezing the palm when greeting, etc.);

- $\quad$ correctly performed wave movement can transfer the accumulated kinetic energy and transform it into the speed of movement in the limbs as the mass of the bio-link decreases ("whip phenomenon");

- $\quad$ body and limb movements performed in wave style are more ergonomic; require less energy for their implementation.

All the above-described effects of vibration-wave impact on the human body (child) in the aquatic environment (pool) only intensify. First of all, it should be noted the wave nature of the water itself, which fluctuates in waves from the movement of any body in it. Even if you just stay (lie) on the surface of the water without performing special corrective movements, the body, along with the water, begins to oscillate in a wave mode. By the way, this wave can be created artificially with the help of a purposeful vibration of some large object in the water (for example, a fitball, or a swimming board, a raft). Another option for wave formation can be the use of directional hydraulic systems like an underwater massage.

This special vibrational state of water can be used to achieve a correction effect in the following areas:

- $\quad$ conjugate the body wave with the water one;

- practice wave-like swimming or separate wave movements of the body (for example, the "dolphin" or "butterfly" method) and limbs;

- the teacher can artificially set a wave impulse to the child's body, holding his arms or legs;

- wave movements of the child's body can be set with the help of two adults (teachers) who simultaneously hold the child's hands and feet;

- $\quad$ the child can perform wave-like movements on his own, imitating the movements of various creatures moving similarly; 
- $\quad$ similar healing movements of the trunk and limbs can be done using a monofin, which is worn on two legs together.

The above effects of wave action in the physical education of children on land are significantly enhanced in the aquatic environment. First, water, due to the Archimedean force, significantly reduces the weight of a child in the water. On the one hand, this helps to relax the skeleton and muscle-fascial formations. On the other hand, the wave motion in the mode of gravitational unloading of the child's body becomes easier and more efficient.

A set of elastic waves forms an acoustic field. In our case, we can talk about a corrective hydroacoustic field (HAF) and its use in overcoming motor disorders in children. The teacher must model the spatial, temporal, and energy parameters of this field to achieve the necessary corrective effect in class. This approach can be demonstrated by the example of the dry immersion (DI) method (Bulgakova, 2008) "The essence of this method is an artificial decrease of gravitational force action in a water environment to reduce the load on the musculoskeletal system, change the muscle tone and pattern of postures and movements. There is no direct contact between the child and water since a medical plastic film is used. This method is especially effective for premature babies, prematurely felt the influence of gravitational forces. In the process of DI sessions implementation, positive dynamics of neurological symptoms, stabilization of several hemodynamic parameters, and a sharp decrease in the size of cephalohematomas were noted" (Bulgakova 2008). In the process of the ascertaining experiment, we tried to combine the antigravity effect of the aquatic environment with the wave effects of water on the child's body (photo 1) and obtained a positive effect in the form of spastic muscles relaxation and optimization of the position of the skeleton in space.

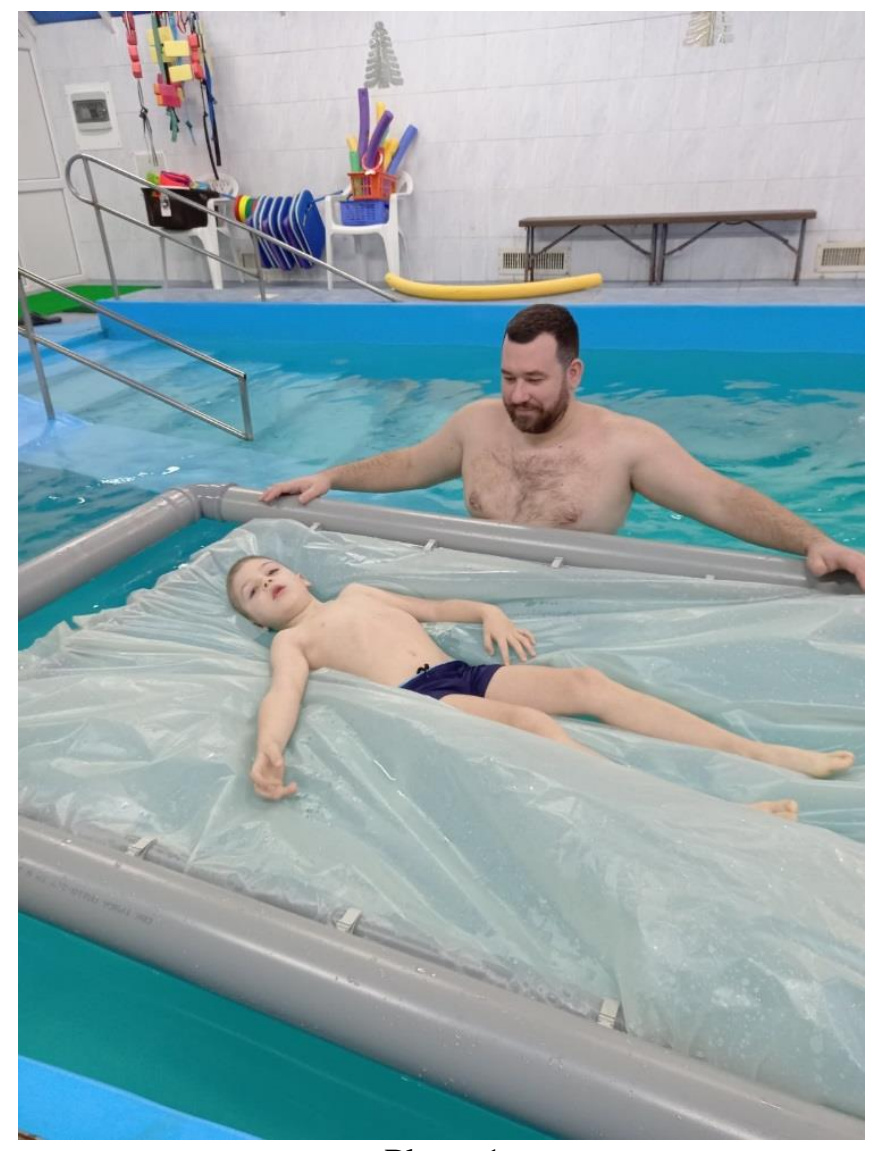

Photo 1

It makes sense to consider the wave phenomenon in three main areas: in conditions of solid support (on land), in an elastic water medium, and an unsupported air space. Speaking about wave movement on land on a solid support, we can talk about the " snake phenomenon", which, having no front and hind limbs, can reach high spatial and temporal indicators: move quickly and even jump! (fig. 1). 


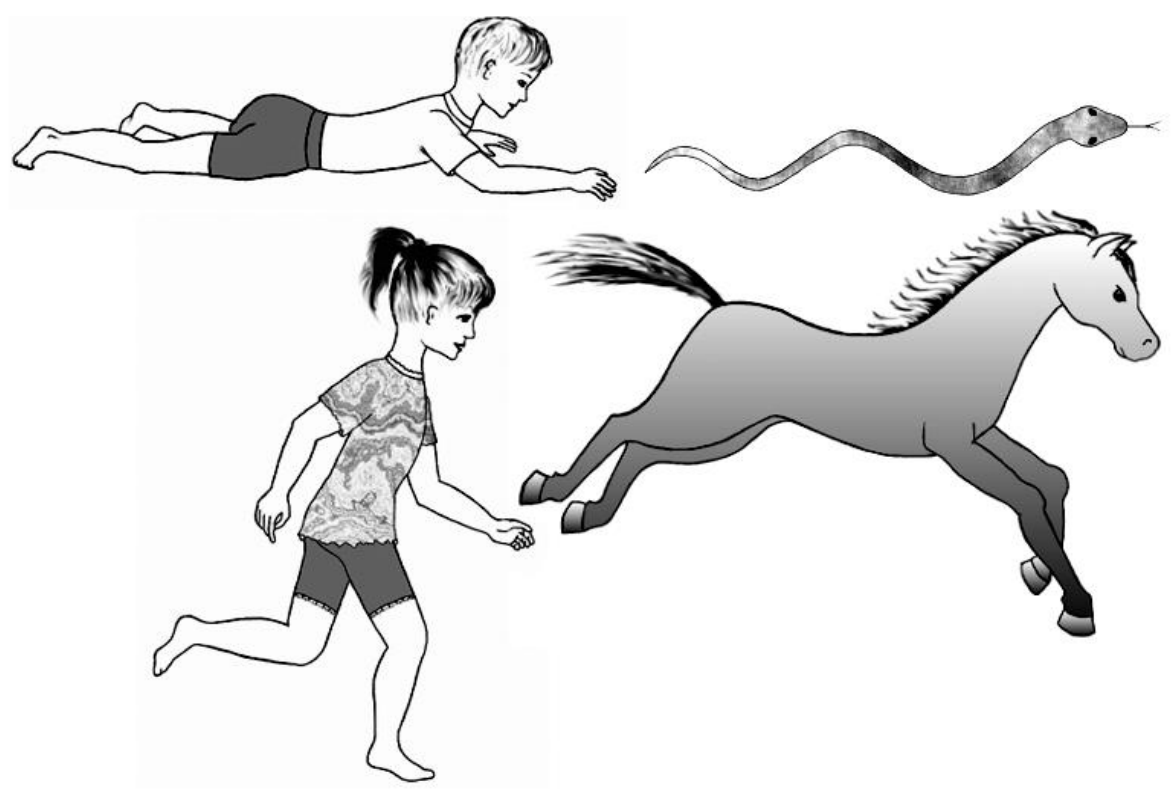

Figure 1. Graphic representation of "Snake phenomenon"

In this case, the presence of support helps her to perform jumps, leaning on her tail. In this case, a wave-like phenomenon is born inside the snake itself due to its muscle contractions, therefore this wave can be called internal. During movement on the support, wave-like movements are directed to the sides, i.e. the emerging waves can be called transverse. While jumping, the snake uses a longitudinal elastic wave. Interaction with solid support allows to independently form internal wave motions of various spatial, temporal, and energy parameters.

This phenomenon is taken as a basis in the aesthetic and health-improving system of N. N. Efimenko, called horizontal plastic ballet (plastic show) (Efimenko, 2015). It is a technique of horizontal parterre movements performed in a slow, flowing, plastic style (the style of a crawling snake). Both individual wave movements on the lower support and paired wave (resonance) interactions of two partners on this support are envisaged. A distinctive feature of such movements is their purposeful slowness, reflecting the following biological regularity: the lower and more horizontal the position of the human body above the support, the more natural it will be for him relatively slow, calm, smooth movements. And here we meet with a contradiction: from the standpoint of biology (physiology, anatomy), horizontal crawling movements should be slow. On the other hand, the effect of wave resonance implies an increase of space-time-energy indicators, including the speed of movement. We see the resolution of this paradox in changing the direction of the wave resonance vector from external to internal. Thus, we can talk about the internal effect of wave resonance, which, with its skillful use, can become a powerful healing force that positively affects the human musculoskeletal system. In other words, instead of a rapid wave movement on a solid support, it is possible to achieve the effect of a dosed restructuring of the entire skeleton of the child, as well as its muscle-fascial formations. These mechanical movements will not be as obvious as external ones, but for their production, all this external kinetic power will be required in order, for example, to stretch at least slightly short, deeply spasmodic muscularligamentous structures that distort the normal anatomical position of the skeleton.

In this variant of interaction with solid support, it is possible to simulate an external wave motion, when the wave impulses will be produced not by the child's body, but carried out from the outside by the efforts of a rehabilitation therapist. For this purpose, we have been using the "Moving Board" simulator - a wooden board mounted on four movable balancers (rubber chambers for balls). Swaying a lying paralyzed child can be performed in all three planes (frontal, sagittal, and horizontal), passing relaxation waves through his body. 
If we consider the movement of living organisms in water, then here we will see the interaction of their bodies and, especially, the caudal fin with an elastic aquatic environment. In this case, we can talk about the "tail fin phenomenon" (Fig. 2). Both longitudinal wave motions (for example, whales) and transverse (like sharks) are used. Therefore, external insignificant vibrations of the head and body of aquatic inhabitants due to the law of conservation of kinetic energy and integral wave motion (Kudryashov, 2011) are transmitted to the caudal fin, significantly increasing its spatial vibrations and, accordingly, speed (Fig. 2)

According to the results of the fish movement analysis, scientists suggested that when swimming, the hammerhead uses two types of oscillations: in addition to the oscillations of the tail fin that are usual for all fish, hammerhead sharks additionally use oscillatory movements of the head. Thus, it is possible to distinguish the forward and backward internal wave motion during swimming.

In the aquatic environment, three main variants of wave motion can be realized:

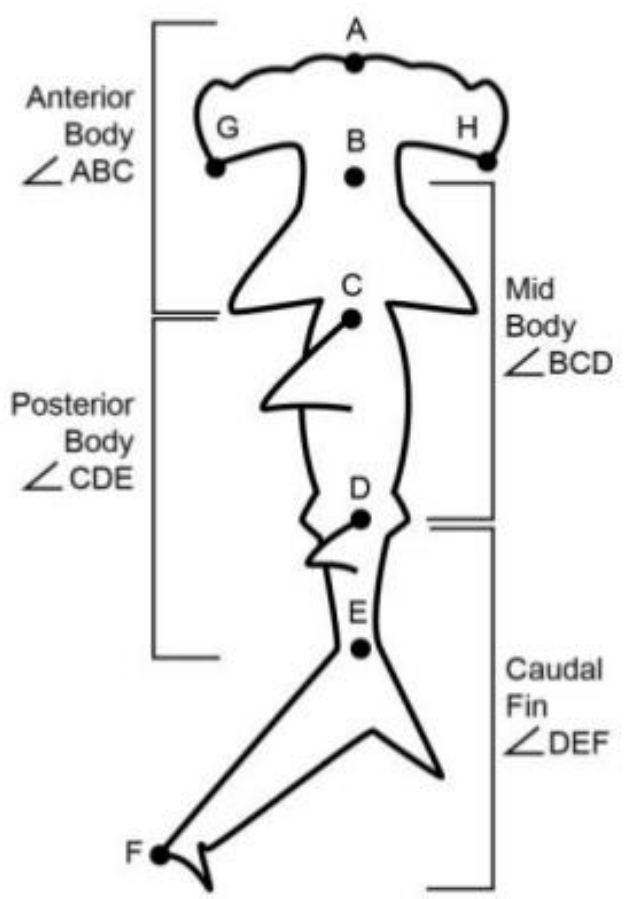

Figure 2. Hammerhead shark body schematic

(S. L. Hoffmann et al./Journal of Experimental Biology, 2017)

1. Variant of internal wave movement - when the water in the pool is static, and a person (child), due to conscious muscle contractions, creates a wave in his body and vibrates the external water environment (interaction of internal and external). At the same time, he can use both the front type of wave movements and the back - it is also possible to combine these movements.

2. Variant of external wave motion - when a sea wave or artificially created waves in the pool carry a person to the shore and he does not apply any physical efforts. This phenomenon is excellently used by surfers, catching the wave and being involved by balancing movements in its rapid flow. Let's call this the "surfing option". In this case, the external wave action remains constant in the process of interaction with the human body. This option can be used in the pool to achieve the necessary oscillatory movements of the skeleton of a child with cerebral palsy lying on the raft.

3. A variant of the combination of the inner and outer waves - when the swimmer intensifies movement on the outer wave with his own directed wave physical efforts.

In the last case, we can talk about the effect of wave resonance, when both waves (internal, external) are superimposed on one (Fig. 3). Resonance is considered to be the phenomenon of a sharp increase in the amplitude of forced oscillations, which occurs when the frequency of forced oscillations coincides with the natural frequency. 


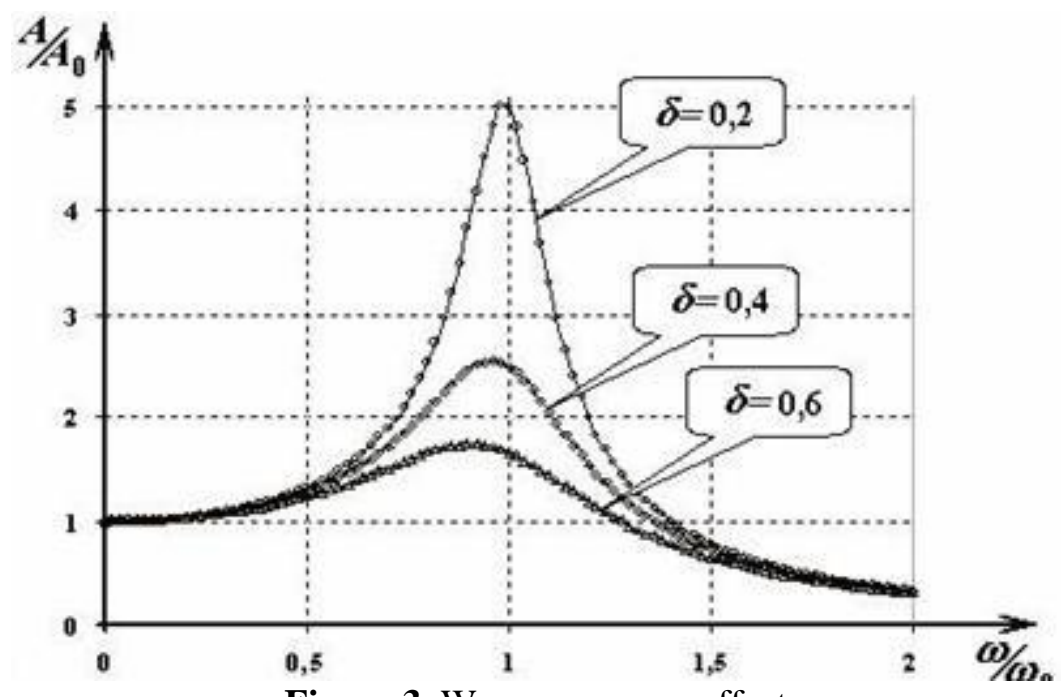

Figure 3. Wave resonance effect

In this case, other space-temporal-energy indicators are also enhanced (distance covered, movement speed, jump range, throw range, hit force, etc.). Perhaps because of this, the Egyptian Bridge collapsed in 1905 in St. Petersburg when a horse squadron was passing through it. A resonant effect arose when the shock vibrations of hundreds of horse legs coincided with the vibrations of the bridge structure, amplifying them to critical indicators, which could cause destruction. But this resonance wave effect, as was shown above, can be not only destructive but also creative, if you learn to control the parameters of wave motion.

The most familiar mechanical resonance system is the common swing. If you push the swing at certain times under its resonant frequency, the range of motion will increase, otherwise, it will fade. The resonant frequency of such a pendulum depends only on one indicator - the length of the cord (rope, cable) from the suspension point of the pendulum to its mass center.

Another classic mechanical resonance system is the string. The strings of well-known musical instruments such as guitar, violin, or piano have a fundamental resonant frequency that directly depends on the length, mass, and tension of the string. The wavelength of the first resonance of the string is equal to its doubled length. The frequency of the main resonance depends on such properties of the string as the tension force, the string mass (its thickness), and the string length. Increasing the tension on the string and decreasing its mass and length increases its resonant frequency.

Both of these mechanical resonance systems (swing and string) can be modeled in the physical rehabilitation of children with musculoskeletal disorders. A child's body in a suspended state (on hands) can be conventionally considered as a swing, and stretched out by the arms and legs - as a conditional string. By choosing the appropriate exercises, it is possible to achieve the effect of mechanical resonance, thereby providing corrective restructuring of the musculoskeletal system as a whole or its individual bio-links.

If we talk about the creation of a wave effect in the conditions of an unsupported air environment, then the most indicative may be the "whip phenomenon", when a ballistic wave from a relatively slow movement on the handle of the whip reaches an enormous speed at its tip! (fig. 4). Thus, there is a transfer of kinetic energy in one closed system. Since the air medium itself remains static (motionless), and the whip transmits an impulse from the movement of the human hand, we can talk about the external version of the wave movement, about the external primary impulse, which propagates further.

This longitudinal wave effect is the most valuable for use in hydrocorrection of the physical development of children with musculoskeletal disorders. A similar phenomenon is observed in the work of the caudal fin of fishes and whales. 


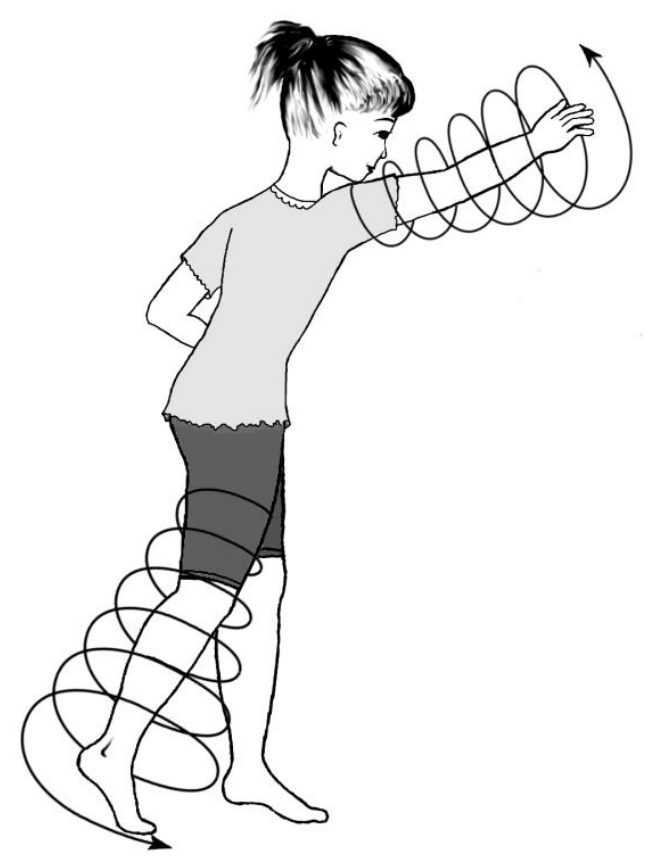

Figure 4. Graphic representation of the "whip phenomenon"

An extreme expression of this wave effect is the typical whiplash injury of the cervical spine that occurs in a passenger or driver when two cars collide. Most often, the vertebrae diverge in space. This traction phenomenon can be purposefully used for dosed stretching of the intervertebral structures using simulated wave-like movements. In this regard, the use of ropes, harnesses in the pool is very effective, with the help of which the necessary wave movements of the child's body on the water surface are simulated (Tyan, 2018).

\section{Conclusion.}

Thus, the vibration-wave effect known in the technical field can be successfully applied in the physical rehabilitation of children with musculoskeletal system disorders on land. In the aquatic environment, these wave phenomena are intensified. This fact inspires its use in corrective and prophylactic swimming of children with musculoskeletal system disorders (Fig. 5). 


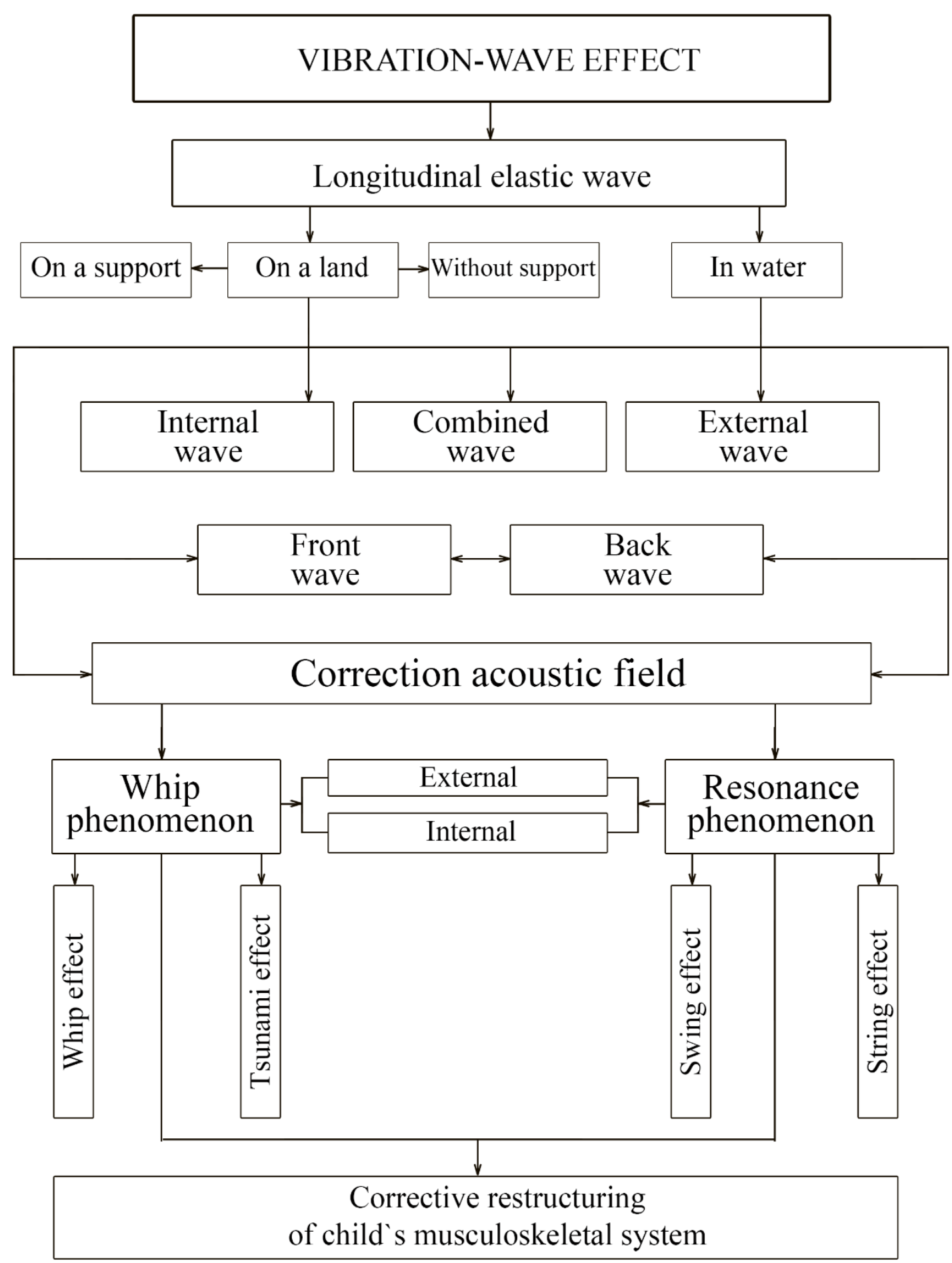

Figure 5. Implementation scheme of vibration-wave effect in physical rehabilitation of children

One of the most powerful healing phenomena of water is its elastic, wave-like consistency. The personal practical experience made it possible to focus on the concept of a longitudinal elastic wave, which creates a corrective hydroacoustic field, which can be modeled in spatial, temporal, and energy parameters under the tasks of children's motor disorders correcting.

A special physical effect is observed when the phenomenon of mechanical wave resonance is achieved, which can be used both according to the external conditional vector, achieving a significant increase in space-time-energy indicators (amplitude, frequency of movements, speed of movement, distance), and to the internal one. In the last case, we can talk about the internal resonant wave effect, with the help of which it is possible to achieve the effect 
of dosed corrective restructuring of the entire musculoskeletal system of the child or its individual bio-links.

\section{REFERENCES}

Aglyamov S., Skovoroda A. (2000). Mekhanicheskiye svoystva myagkikh biologicheskikh tkaney. [Mechanical properties of soft biological tissues]. Biophysics. 45 (6). p. 1137-1145 [in Rus].

Blekhman I. (1988). Chto mozhet vibratsiya? O "vibratsionnoy mekhanike" $i$ vibratsionnoy tekhnike. [What can vibration? About "vibration mechanics" and vibration technology]. Moscow: Nauka, p. 208 [in Rus].

Borshchenko I. (2011). Izometricheskaya gimnastika doktora Borshchenko. Pozvonochnik i sustavy. Polnyy kurs uprazhneniy. [Isometric gymnastics of Dr. Borshchenko. Spine and joints. Complete exercise course]. Moscow: Astrel: Metaphor, p. 349 [in Rus].

Bulgakova G., Morozov N., Popov I. (2008). Ozdorovitel'noye, lechebnoye i adaptivnoye plavaniye. [Recreational, therapeutic and adaptive swimming]. Moscow: Academy, p. 432 [in Rus].

Efimenko M. (2013). Suchasni pidkhody do korektsiyno spryamovanoho fizychnoho vykhovannya doshkil'nykiv z porushennyamy oporno-rukhovoho aparatu. [Modern approaches of correctional physical education of preschoolers with musculoskeletal system disorders]. Vinnytsia: Nilan-LTD, p. 356 [in Ukr].

Efimenko M., Melnichenko Yu. (2015). Prohrama z fizkul'turno-korektsiynoyi roboty u doshkil'nykh navchal'nykh zakladakh za avtors'koyu estetyko-ozdorovchoyu systemoyu "Horyzontal'nyy plastychnyy balet (plastyk-shou). [The program of physical culture and correctional work in preschool educational institutions according to the author's aesthetic and health system "Horizontal plastic ballet (plastic show)"]. Vinnytsia: Nilan-LTD, p. 56 p [in Ukr].

Efimenko N. (2001). Gorizontal'nyy plasticheskiy balet: novaya sistema fizicheskogo vospitaniya, ozdorovleniya i tvorcheskogo samovyrazheniya detey $i$ vzroslykh. [Horizontal plastic ballet: a new system of physical education, health improvement and creative self-expression of children and adults]. Taganrog: Cognition, p. 176 [in Rus].

Efimenko N., Litvyakov M. (2019). AKVA-TEATR: partsial'naya programma adaptatsii detey rannego $i$ doshkol'nogo vozrasta $k$ vodnoy srede $i$ obucheniya plavaniyu. [AQUA-THEATER: a partial program of adaptation of children of early and preschool age to the aquatic environment and learning to swim]. Vinnytsia: Create, p. 100 [in Rus].

Frolov V. (1989). Vibratsionnaya biomekhanika. [Vibration biomechanics]. Moscow: Nauka, p. 143 [in Rus].

Irodov I. (2020). Volnovyye protsessy. Osnovnye zakoni. [Wave processes. Basic laws]. Moscow: knowledge laboratory, p. 226 [in Rus].

Kaunsilman D. (1971). Nauka o plavanii. [Swimming Science]. Moscow: Physical culture and sport, p. 432 $\mathrm{p}$ [in Rus].

Klochkov B. (2000). Nelineynyye vibroakusticheskiye protsessy na poverkhnosti tkani. [Nonlinear vibroacoustic processes on the surface of tissue]. Acoustic journal, 46 (5). p 707-709 [in Rus].

Klochkov B. (2008). Volnovyye protsessy v aktivnikh seredakh, nasyshchennykh zhidkost'yu. [Wave processes in active media saturated with liquid]. (Unpublished doctoral dissertation). Moscow [in Rus].

Korchagin E., Zhuravlev A., Stenin Yu. (2014). Fizika volnovykh protsessov. [Physics of wave processes]. Kazan: KFU Publishing House, p. 77 [in Rus].

Krasilnikov V., Krylov V. (1984). Vvedeniye v fizicheskuyu akustiku. [Introduction to physical acoustics]. Moscow: Nauka, p. 400 [in Rus].

Krasilnikov V., Krylov V. (1985). Poverkhnostnyye akusticheskiye volny. [Surface acoustic waves]. Moscow: Knowledge, p. 64 [in Rus].

Kravchenko I. (2011). Teoriya volnovykh protsessov. [The theory of wave processes]. Moscow. P. 240 [in Rus].

Kudryashov N. (2011). Gimnastika giperboreyev. Tselitel'naya vibratsiya. [Hyperborean gymnastics. Healing vibration]. Saint-Petersburg: Peter, p. 192 [in Rus].

Landau L., Lifshits E. (1986). Gidrodinamika. [Hydrodynamics]. Moscow: Nauka, p. 736 [in Rus].

Moiseeva V. (2017). Volnovaya pedagogika Detstva: Yedinaya obrazovatel'naya konstanta. Volno-vyye tekhnologii obrazovaniya v DOU. Teoriya i praktika. [Wave Pedagogy of Childhood: A Unified Educational Constant. Wave technologies of education in preschool educational institutions. Theory and practice]. Ekaterinburg: Publishing House "Azhur", p. 198 [in Rus].

Romanov S. (1983). Biologicheskoye deystviye mekhanicheskikh kolebaniy. [Biological action of mechanical vibrations]. Saint-Petersburg: Nauka, p. 208 [in Rus].

Romanov S. (1991). Biologicheskoye deystviye vibratsii i zvuka. [Biological action of vibration and sound]. Saint-Petersburg: Nauka, p. 160 [in Rus]. 
Solovyanova P., Shabunin S. (2004). Teoriya volnovykh protsessov: Akusticheskiye volny. [Theory of wave processes: Acoustic waves]. Ekaterinburg: GOU VPO USTU-UPY, p. 142 [in Rus].

Aksenova R., Antonets V. (1989, June). Izmereniye lokal'nykh poverkhnostnykh kolebaniy biologicheskikh tkaney massivnym vibropreobrazovatelem. [Measurement of local surface vibrations of biological tissues with a massive vibration transducer. Measurements in medicine and their metrological support]. 9th All-Union conference (p. 57). Moscow: VNIIOFI [in Rus].

Golubeva A., Klochkov B. (1994, November). Vliyaniye vibratsii na myagkiye tkani cheloveka. [Influence of vibration on human soft tissues]. 2-nd All-Russian conference on biomechanics (pp. 35-36). N. Novgorod: Publishing house N. Novgorod [in Rus].

Tyan S. (2018). Avtorskiy opyt obucheniya doshkol'nikov 3-7 let plavaniyu na osnove teatralizatsii sovmestnoy obrazovatel'noy deyatel'nosti s primeneniyem vspomogatel'nykh sredstv. [Author's experience of teaching preschoolers 3-7 years old to swim on the basis of theatricalization of joint educational activities with the use of aids]. Matveev Kurgan, p. 15 [in Rus]. 